\title{
Changes in elastic modulus, leaf tensity and leaf density during dehydration of detached leaves in two plant species of Moraceae
}

\author{
Deke Xing ${ }^{1 * 3}$, Xiaole Chen ${ }^{1}$, Yanyou $\mathrm{Wu}^{2}$, Zhenyi $\mathrm{Li}^{1}$, and Shanjida Khan ${ }^{3}$ \\ ${ }^{1}$ Jiangsu University, Key Laboratory of Modern Agricultural Equipment and Technology, Ministry of Education, Institute of Agricultural \\ Engineering, 212013, Zhenjiang, P.R. China. ${ }^{*}$ Corresponding author (xingdeke@ujs.edu.cn). \\ ${ }^{2}$ Research Center for Environmental Bio-Science and Technology, State Key Laboratory of Environmental Geochemistry, Institute of \\ Geochemistry, Chinese Academy of Sciences, 550081, Guiyang, P.R. China. \\ ${ }^{3}$ University of Alberta, Department of Renewable Resources, Edmonton, AB, T6G 2E3, Canada.
}

Received: 19 November 2020; Accepted: 20 February 2021; doi:10.4067/S0718-58392021000300434

\begin{abstract}
The quick adjustments of leaf traits are critical for keeping the survival of plants under dehydration. In this study, we examined the hypotheses that plants would adapt to dehydration by shrinking its mesophyll cells to offset the water loss, or triggering water regulation mechanism caused by enzymes. Leaf structure, elastic modulus ( $\mathrm{E}_{\mathrm{m}}$ ), leaf tensity (LT) and leaf density (LD) were determined with detached leaves of Broussonetia papyrifera (L.) Vent. and Morus alba L. at each water loss moment $(0,1,2,3,4$ and $5 \mathrm{~h})$. The coupling model between gripping force and LT was established using the Gibbs free energy equation, and the initial LT was determined. The intracellular water availability of $M$. alba decreased at $4 \mathrm{~h}$, which was earlier than that of B. papyrifera. The intracellular water availability of M. alba was more sensitive than B. papyrifera. Broussonetia papyrifera adapted to dehydration by shrinking its mesophyll cells to offset the water loss, or triggering water regulation mechanism caused by enzymes, i.e., carbonic anhydrase. The sponge parenchyma of B. papyrifera at 3 $\mathrm{h}$ decreased by $25.73 \%$ of that at control. Morus alba maintained intracellular water availability just by changing the leaf structure. The offset effects through shrinking cells differed between B. papyrifera and M. alba, because the elastic-plastic behavior of their leaves and cells were different. The $\mathrm{E}_{\mathrm{m}}$ of M. alba was over five-fold higher than that of B.papyrifera. The investigations of water status were more accurate in terms of leaf physical traits instead of water content.
\end{abstract}

Key words: Anatomical structure, Broussonetia papyrifera, cell volume, leaf tensity, mechanical strength, Morus alba, water translocation.

\section{INTRODUCTION}

As leaves open their stomata to capture $\mathrm{CO}_{2}$ for photosynthesis, water is lost to transpiration (Scoffoni et al., 2014). Daily maximum temperatures may contribute to limitations in gas exchange by increasing the vapor pressure difference between leaves and the air (Mahmoodi-Sourestani, 2013). Leaf water potential follows a circadian rhythm parallel to the evaporative demand of the atmosphere (García-Orellana et al., 2013). The quick adjustments of leaf traits for balancing water supply and demand are critical for keeping the survival of plants under water deficit (Zhang et al., 2019). Leaf shrinkage occurs as transpiration dehydrates the leaf, and its leaf water potential decreases sufficiently to absorb water. If the water absorption is limited, shrinkage can be especially noticeable. Shrinkage enhances the tightness of the leaves against water loss, thus affecting features known to control the diffusion of water vapor out of the leaf (Boyer, 2015). Stomata can rapidly respond to dehydration and reduce openness, and is the dominant limitation to photosynthesis (Salgado-Aguilar et al., 2020). However, the intracellular water used in the photosynthetic process can be regulated either by the enzymes, i.e., carbonic anhydrase, or by the variations of leaf features, which help to maintain the photosynthetic capacity. 
One of the central variables among the leaf traits is leaf anatomical structure. Plants adopt morphological adaptation strategies by altering the anatomical structures to prevent water loss in the process of transpiration (Wyka et al., 2019; Vastag et al., 2020). Water deficit conditions cause increases in thickness of spongy parenchyma, upper palisade, trichome layer, upper and lower epidermis, and leaf lamina (Ennajeh et al., 2010). Thicker leaves, stratum corneum, and developed palisade parenchyma enhance water storage capacity and show strong drought resistance (Zhang et al., 2013). Leaf thickness is positively correlated with leaf hydraulic conductivity and has a tight relationship with water status (Scoffoni et al., 2014). However, leaf thickness may vary by species and leaf position on the plant, the relationship between leaf thickness and water content is affected by environmental variables (Afzal et al., 2017). Leaf mass per area (LMA) is an important leaf trait that is strongly correlated with leaf functional, biochemical and structural traits; the variation in LMA is more closely related to leaf density (LD) than to leaf thickness (Xiong et al., 2016). Leaf density and leaf thickness explain $80 \%$ and $20 \%$ of the differences in LMA, respectively (Poorter et al., 2009).

Water deficit also results in cell wall hardening and larger elastic modulus $\left(\mathrm{E}_{\mathrm{m}}\right)$, which helps the tissue maintain turgor pressure and avoid water stress (Malgat et al., 2016). Leaf elastic modulus is independent of leaf thickness and is weakly related to LMA. Changes in LD cause modifications in leaf elasticity and allow tolerance of water limitations (Méndez-Alonzo et al., 2019). Leaf density is structurally, functionally, and developmentally linked to a wide range of traits that influence leaf water balance (Sun et al., 2014). Numerous physiological and biochemical changes in leaves induced by water availability are the main factors contributing to plant drought resistance (El-Sayed et al., 2019). The variations of plant cell volume and cell sap concentration are closely correlated with electrophysiological index, such as leaf tensity (LT), LT exhibits a better relationship with net photosynthetic rate than leaf water potential (Zhang et al., 2015). The determination of electrophysiological index provides an accessible way of investigating intracellular water status. Leaf morphological and anatomical traits are important contributors of leaf water balance between hydraulic supply and evaporative loss, which benefit the photosynthesis (Sun et al., 2014; Li et al., 2020). However, the influences of leaf anatomical structures and cell volume variations on intracellular water availability under dehydration stress are still unknown.

Broussonetia papyrifera (L.) Vent. and Morus alba L., belonging to Moraceae, are characterized by a higher growth rate and greater adaptability to adverse environments (Wu et al., 2009). They are always cultivated as medicinal, ornamental and economic plants. Broussonetia papyrifera is an important typical pioneer species (Huang et al., 2019). Research has revealed that $B$. papyrifera exhibited better drought resistance than $M$. alba due to its higher bicarbonate use capacity and better water status (Wu and Xing, 2012). To our knowledge, there is still no report on the difference of the adaptive mechanisms of these two Moraceae plant species to dehydration in terms of electrophysiology and mechanical strength. Hence the detached leaves of B. papyrifera and M. alba were selected as the experimental materials in this study.

The objectives of this study were to investigate the leaf anatomical structures, cell wall traits and intracellular water status; and to analyze the intracellular water availability in terms of leaf physical traits. Since the controlled dehydration can be more easily and reliably attained, a higher number of replicates are possible and interpretation of the results may be facilitated by the fact that changes recorded during dehydration are generated completely in the leaf without any contribution by other leaves or other parts of the plant via the vascular system (Bochicchio et al., 1998). Therefore, the detached leaves were soaked in double distilled water for $30 \mathrm{~min}$ and then exposed to rapid water loss in this study. The difference of leaf intracellular water status of the two species was investigated by comparing the corresponding changes in leaf anatomical structure, mechanical strength, leaf relative water content (RWC), LT, LD and maximum photosystem II (PSII) quantum yield $\left(\mathrm{F}_{\mathrm{v}} / \mathrm{F}_{\mathrm{m}}\right)$ at different water loss time. We hypothesized that plants would adapt to dehydration by shrinking its mesophyll cells to offset the water loss, or triggering water regulation mechanism caused by enzymes, which would maintain the intracellular water availability.

\section{MATERIALS AND METHODS}

\section{Plant materials}

The experiment was performed in a growth chamber at Jiangsu University, Jiangsu Province $\left(32.20^{\circ} \mathrm{N}, 119.45^{\circ} \mathrm{E}\right)$, China. Broussonetia papyrifera (L.) Vent. and Morus alba L. plants, which grew in yellow-brown soil on a sunny slope, were selected as the experimental materials. The area receives a mean annual precipitation of approximately $1100 \mathrm{~mm}$ and has a mean annual air temperature of about $15.6^{\circ} \mathrm{C}$. Fresh branches from the two Moraceae plants were picked in August. 
Leaves growing uniformly were taken from the fourth and fifth leaf positions of each branch. Leaf picking was completed between 09:00-10:00 $\mathrm{h}$ in the morning. The fresh leaves removed from the branches were placed in double distilled water immediately and soaked for $30 \mathrm{~min}$, in order to keep all the leaves in a uniform initial state (water-saturated), which could accurately make the comparison between different plant species. After soaking, the moisture on the surface of the leaves was wiped and removed with tissues. Finally, the detached leaves were constantly placed on a dry ventilated desktop for $5 \mathrm{~h}$ at $26^{\circ} \mathrm{C}$, photosynthetic photon flux density (PPFD) was $160 \mu \mathrm{mol} \mathrm{m}^{-2} \mathrm{~s}^{-1}$, and relative air humidity was $40 \%$. Measurements were done in quintuplicate at 0 (baseline), 1, 2, 3, 4 and $5 \mathrm{~h}$ after dehydration.

\section{Determination of leaf water content and leaf area}

Leaf area $\left(\mathrm{LA}, \mathrm{cm}^{2}\right)$ was obtained by scanning with a broad-leaved image analysis system (WinFOLIA, Regent Instruments Inc., Quebec, Canada). The fresh weight of leaves (FW, g) was recorded and leaves were immersed in double distilled water. After $2 \mathrm{~h}$, leaves were removed, surface water was blotted-off and the turgid weight (TW, g) was recorded. Leaves were then dried in an oven at $80{ }^{\circ} \mathrm{C}$ to constant weight (DW, g). Leaf relative water content (RWC, \%) was calculated using the following formula (Pirzad et al., 2011):

$$
\mathrm{RWC}=\frac{\mathrm{FW}-\mathrm{DW}}{\mathrm{TW}-\mathrm{DW}} \times 100
$$

\section{Leaf anatomy measurement}

Leaf anatomy was observed according to the paraffin sectioning method $(\mathrm{Li}, 1978)$. Small leaf pieces $(0.5 \times 0.5 \mathrm{~cm})$ were cut off between the main veins and immersed under the formalin-acetic acid-alcohol (FAA) fixing solution (5\% formaldehyde, 5\% acetic acid and 90\% alcohol). All leaf sections were 8-10 $\mu \mathrm{m}$ thick. These paraffin sections were stained with safranin and fast green dye and permanently mounted on slides. Samples were observed by using inverted light microscopes (DMi8, Leica, Wetzlar, Germany), and images were taken. The leaf total thickness $\left(D_{t}, \mu \mathrm{m}\right)$, upper and lower epidermis thickness, palisade parenchyma thickness, sponge parenchyma thickness, and ratio (\%) of palisade parenchyma to spongy parenchyma thickness were measured by the ImageJ software (National Institutes of Health [NIH], Bethesda, Maryland, USA). Tightness degree of leaf tissue structure (CTR, \%) is the ratio of palisade parenchyma thickness to leaf thickness, and loose degree of leaf tissue structure (SR,\%) is the ratio of sponge parenchyma thickness to leaf thickness.

\section{Leaf elastic modulus measurement}

The increased stresses $\left(\mathrm{F}_{\mathrm{s}}, \mathrm{N}\right)$ with increasing deformation rates $(\Delta \mathrm{X}, \%)$ of leaf at each water loss moment were recorded with the texture analyzer TA.XTplusC (Stable Micro Systems, Godalming, Surrey, UK) using the P/2n probe with a diameter of $2 \mathrm{~mm}$. The instrument working parameters were determined by the test mode compression; with pretest speed at $2 \mathrm{~mm} \mathrm{~s}^{-1}$, test speed at $1 \mathrm{~mm} \mathrm{~s}^{-1}$, post-test speed at $2 \mathrm{~mm} \mathrm{~s}^{-1}$. The leaf elastic modulus ( $E_{\mathrm{m}}, \mathrm{N}$ per unit deformation) was then calculated according to Equation 2 as follows:

$$
\mathrm{F}_{\mathrm{s}}=\mathrm{E}_{\mathrm{m}} \times \Delta \mathrm{X}
$$

\section{Determination of physiological capacitance at different gripping forces}

The variation of physiological capacitance $(\mathrm{CP}, \mathrm{pF})$ with increased gripping forces at each water loss moment was determined by using the LCR HiTester (model 3532-50, Hioki, Nagano, Japan) with a frequency and voltage of $3 \mathrm{kHz}$ and $1 \mathrm{~V}$, respectively (Xing et al., 2019). Each leaf was clipped onto the custom-made parallel-plate capacitor (Figure 1). The value of LT $\left(\mathrm{cm}^{2} \mathrm{~cm}^{-1}\right)$ was calculated according to Equation 3 (Zhang et al., 2015):

$$
\mathrm{LT}=\frac{\mathrm{A}_{\mathrm{CP}}}{\mathrm{d}_{\mathrm{L}}}=\frac{\mathrm{CP}}{\varepsilon_{0}}\left[\frac{1000 \mathrm{iRT}}{81000 \mathrm{iRT}+(81-\mathrm{a}) \mathrm{M \Psi}_{\mathrm{L}}}\right]
$$

where $A_{C P}\left(\mathrm{~cm}^{2}\right)$ is the effective area of the leaf in contact with the capacitor plates, $d_{L}(\mathrm{~cm})$ is the leaf effective thickness; $\varepsilon_{0}$ is the vacuum dielectric constant (with value of $8.854 \times 10^{-12} \mathrm{~F} \mathrm{~m}^{-1}$ ); i is the dissociation coefficient (with value of 1 ); $\mathrm{R}$ is the gas constant (with value of $\left.8.30 \times 10^{-3} \mathrm{~L} \mathrm{MPa} \mathrm{mol}^{-1} \mathrm{~K}^{-1}\right)$; $\mathrm{T}$ is the thermodynamic temperature $\left(\mathrm{T}=273+\mathrm{t}^{\circ} \mathrm{C}, \mathrm{K}\right) ; 81$ is the relative dielectric constant of water at normal temperature; a is the relative dielectric constant of the cytosol solute; $\mathrm{M}$ is the relative molecular mass of the cytosol solute $\left(\mathrm{g} \mathrm{mol}^{-1}\right)$; and $\Psi_{\mathrm{L}}(\mathrm{MPa})$ is the leaf water potential. In this study, the sucrose $\mathrm{C}_{12} \mathrm{H}_{22} \mathrm{O}_{11}$ was identified as the solute in the cytosol; therefore, a was $3.30, \mathrm{M}$ was $342 \mathrm{~g} \mathrm{~mol}^{-1}$, and t was $20^{\circ} \mathrm{C}$. 
Figure 1. Schematic diagram of the parallel-plate capacitor. 1: bracket; 2: foam board; 3: electrode; 4: wire; 5: iron; 6: plastic bar; 7: bench holdfast.

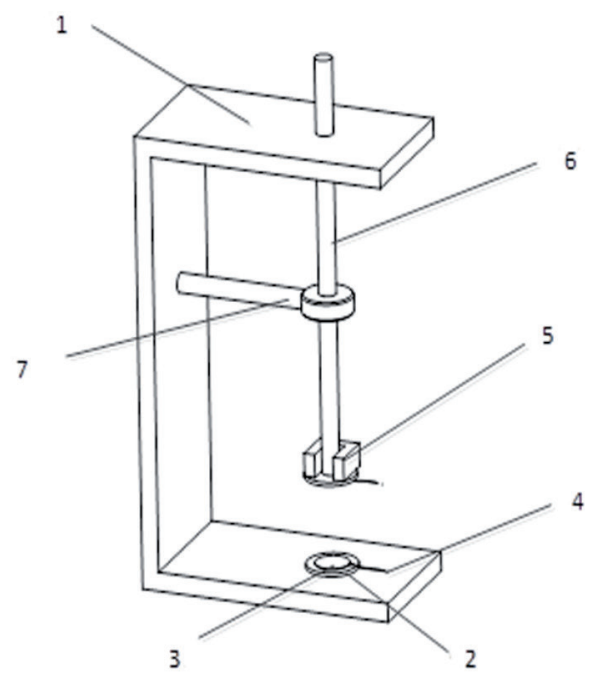

\section{Calculation of initial leaf tensity and leaf density}

The following equation was used to calculate gripping forces $\left(\mathrm{F}_{\mathrm{g}}, \mathrm{N}\right)$, which are used for clamping a leaf during the $\mathrm{CP}$ measurement:

$$
F_{g}=\left(M_{i}+m\right) g
$$

where $\mathrm{F}_{\mathrm{g}}$ is the gravity (gripping force, $\left.\mathrm{N}\right), \mathrm{M}_{\mathrm{i}}$ is the mass of iron $(\mathrm{kg}), \mathrm{m}$ is the mass of the foam board and electrode $(\mathrm{kg})$, and $\mathrm{g}$ is the acceleration of gravity with value of $9.8 \mathrm{~N} \mathrm{~kg}^{-1}$.

Electrophysiological behavior of a plant is closely related to that of a single cell, and the cell can be presumed as a spherical capacitor. Cytosol solute in the leaf is taken as the dielectric. The leaf is clipped between the two electrodes of the parallel-plate capacitor. At different gripping forces, $\mathrm{CP}$ can be determined by changing the iron mass in the capacitor (Figure 1). The cytosol solute concentration and elasticity and plasticity of the cells change as the pressure varies, which causes dielectric constant variation in the cytosol solute and $\mathrm{CP}$ between the two electrodes of the parallel-plate capacitor.

The equation for Gibbs's free energy is:

$$
\Delta \mathrm{G}=\Delta \mathrm{H}+\mathrm{PV}
$$

The equation for the energy of capacitor is:

$$
\mathrm{W}_{\mathrm{C}}=\frac{1}{2} \mathrm{U}^{2} \mathrm{CP}
$$

where $\mathrm{W}_{\mathrm{C}}$ is the energy of the capacitor, which is equal to the work converted from Gibbs's free energy $\left(\Delta \mathrm{G}, \mathrm{W}_{\mathrm{C}}=\Delta \mathrm{G}\right)$; $\Delta \mathrm{H}$ is the internal energy of the system composed of cells in the plant leaves; $\mathrm{P}$ is the pressure imposed on the plant cells, $\mathrm{V}$ is the volume of plant cells; and $\mathrm{U}$ is the test voltage.

The value of $\mathrm{P}$ can be calculated using the following equation:

The $\mathrm{CP}$ of the leaf was expressed using Equation 8:

$$
\mathrm{P}=\frac{\mathrm{F}_{\mathrm{g}}}{\mathrm{A}_{\mathrm{CP}}}
$$

$$
\mathrm{CP}=\frac{\varepsilon_{0} \varepsilon_{\mathrm{r}} \mathrm{A}_{\mathrm{CP}}}{\mathrm{d}_{\mathrm{L}}}
$$

where $\varepsilon_{0}$ is the vacuum dielectric constant with value of $8.854 \times 10^{-12} \mathrm{~F} \mathrm{~m}^{-1}$, and $\varepsilon_{\mathrm{r}}$ is the relative dielectric constant of the cytosol solute.

According to Equations 3, 5, 6, 7, and 8, the relationship between $\mathrm{LT}$ and $\mathrm{F}_{\mathrm{g}}$ could be expressed as follows:

$$
\mathrm{LT}=\frac{2 \Delta \mathrm{H}}{\varepsilon_{0} \varepsilon_{\mathrm{r}} \mathrm{U}^{2}}+\frac{2 \mathrm{~V}}{\varepsilon_{0} \varepsilon_{\mathrm{r}} \mathrm{A}_{\mathrm{CP}} \mathrm{U}^{2}} \mathrm{~F}_{\mathrm{g}}
$$


Incorporating $\frac{2 \Delta \mathrm{H}}{\varepsilon_{0} \varepsilon_{\mathrm{r}} \mathrm{U}^{2}}$ and $\frac{2 \mathrm{~V}}{\varepsilon_{0} \varepsilon_{\mathrm{r}} \mathrm{A}_{\mathrm{CP}} \mathrm{U}^{2}}$ into Equation 9 changes this equation to:

$$
\mathrm{LT}=\mathrm{y}_{0}+\mathrm{kF}_{\mathrm{g}}
$$

where $\mathrm{y}_{0}$ and $\mathrm{k}$ are the model parameters.

The relationship curve between LT and $\mathrm{F}_{\mathrm{g}}$ was established using SigmaPlot v.12.5 (Systat Software, San Jose, California, USA). The relationship between LT and $\mathrm{F}_{\mathrm{g}}$ was fitted. The model parameters $\mathrm{y}_{0}$ and $\mathrm{k}$ would be estimated.

According to Equation 10, the initial leaf tensity $\left(\mathrm{LT}_{0}, \mathrm{~cm}^{2} \mathrm{~cm}^{-1}\right)$ can be calculated when the $\mathrm{F}_{\mathrm{g}}$ equal to $0, \mathrm{LT}_{0}$ can be expressed as follows:

Leaf density ( $\left.\mathrm{LD}, \mathrm{g} \mathrm{cm}^{-3}\right)$ was calculated as follows:

$$
\mathrm{LD}=\frac{\mathrm{DW}}{\mathrm{D}_{\mathrm{t}} \times \mathrm{LA}} \times 10^{4}
$$

where DW $(\mathrm{g})$ is the leaf dry weight, $\mathrm{D}_{\mathrm{t}}(\mu \mathrm{m})$ is the leaf total thickness, $\mathrm{LA}\left(\mathrm{cm}^{2}\right)$ is the leaf area.

\section{Maximum PSII quantum yield $\left(\mathbf{F}_{\mathrm{v}} / \mathbf{F}_{\mathrm{m}}\right)$ measurement}

Chlorophyll fluorescence (ChlF) was measured with IMAGING-PAM modulated ChlF imaging system (Heinz Walz $\mathrm{GmbH}$, Effeltrich, Germany). Leaves were dark adapted for $30 \mathrm{~min}$ to ensure complete relaxation of all reaction centers before the measurements. The minimum $\mathrm{ChlF}\left(\mathrm{F}_{\mathrm{o}}\right)$ was determined using a measuring beam, whereas the maximum $\mathrm{ChlF}$ $\left(\mathrm{F}_{\mathrm{m}}\right)$ was recorded after a $0.8 \mathrm{~s}$ saturating light pulse $\left(6000 \mu \mathrm{mol} \mathrm{m} \mathrm{m}^{-2} \mathrm{~s}^{-1}\right)$. Maximum PSII quantum yield $\left(\mathrm{F}_{\mathrm{v}} / \mathrm{F}_{\mathrm{m}}\right)$ was calculated as $\left(\mathrm{F}_{\mathrm{m}}-\mathrm{F}_{\mathrm{o}}\right) / \mathrm{F}_{\mathrm{m}}$.

\section{Statistical analysis}

All collected data were analyzed using SPSS Statistics 22.0 software (SPSS, IBM, Armonk, New York, USA). Significant differences between stress levels were assessed using the least significant difference post-hoc test at $5 \%$ significance level $(\mathrm{p} \leq 0.05)$. The data are shown as the means $\pm \mathrm{SE}(\mathrm{n}=5)$ determined using the one-sample $\mathrm{t}$-test. The confidence interval was $95 \%$.

\section{RESULTS}

\section{Effects of dehydration on leaf water content and leaf area}

The values of RWC of B. papyrifera showed more significant decrease at $1 \mathrm{~h}$ than that of M. alba (Table 1). After the moment of $3 \mathrm{~h}$ water loss, RWC of $M$. alba became lower than that of $B$. papyrifera. There was nonsignificant difference between the values of RWC in B. papyrifera at 3, 4 and $5 \mathrm{~h}$ water loss moments. And lower value of RWC was consistently associated with longer water loss time in M. alba. There was nonsignificant difference between the values of leaf area (LA) in B. papyrifera at each water loss moment (Table 1). A clear decrease of LA with increased water loss time was observed in $M$. alba.

\section{Changes of leaf anatomical structure and elastic modulus}

As water loss time increased, leaf total thickness of B. papyrifera decreased significantly at $2 \mathrm{~h}$, and then increased and reached the highest value at $5 \mathrm{~h}$ (Table 2). Broussonetia papyrifera exhibited the lowest value of upper epidermis thickness at $2 \mathrm{~h}$ and the highest value at $5 \mathrm{~h}$. Higher value of palisade parenchyma thickness was associated with longer water loss time. Sponge parenchyma thickness decreased with increased water loss time, and exhibited the lowest value at $2 \mathrm{~h}$, the highest value in B. papyrifera was observed at $4 \mathrm{~h}$. Lower value of lower epidermis thickness was associated with longer water loss time.

Leaf total thickness of $M$. alba decreased as water loss time increased, but there was no significant difference between the values at 3,4 and $5 \mathrm{~h}$ (Table 2). Upper epidermis thickness at 4 and $5 \mathrm{~h}$ were significantly lower than those at $0,1,2$ and $3 \mathrm{~h}$, and the values at 1 and $2 \mathrm{~h}$ were significantly higher than those at the other water loss moments. Palisade parenchyma thickness at 3,4 and $5 \mathrm{~h}$ were clearly lower than those at the other water loss moments, there was nonsignificant difference 
Table 1. Effect of dehydration on leaf relative water content (RWC) and leaf area (LA) of Broussonetia papyrifera and Morus alba.

\begin{tabular}{|c|c|c|c|c|}
\hline \multirow[b]{2}{*}{ Water loss time (h) } & \multicolumn{2}{|c|}{ RWC } & \multicolumn{2}{|c|}{ LA } \\
\hline & B. papyrifera & M. alba & B. papyrifera & M. alba \\
\hline & & 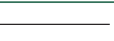 & 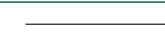 & $\bar{u}$ \\
\hline 0 & $\begin{array}{r}100.00 \mathrm{a} \\
(0.00)\end{array}$ & $\begin{array}{c}100.00 \mathrm{u} \\
(0.00)\end{array}$ & $\begin{array}{r}104.07 \mathrm{a} \\
(1.88)\end{array}$ & $\begin{array}{c}48.27 \mathrm{u} \\
(0.92)\end{array}$ \\
\hline 1 & $\begin{array}{c}65.06 \mathrm{~b} \\
(0.02)\end{array}$ & $\begin{array}{l}76.22 \mathrm{v} \\
(0.01)\end{array}$ & $\begin{array}{r}104.31 \mathrm{a} \\
(1.41)\end{array}$ & $\begin{array}{c}\text { 47.46uv } \\
(0.76)\end{array}$ \\
\hline 2 & $\begin{array}{l}54.64 \mathrm{c} \\
(0.02)\end{array}$ & $\begin{array}{l}58.67 \mathrm{w} \\
(0.01)\end{array}$ & $\begin{array}{r}103.04 \mathrm{a} \\
(1.09)\end{array}$ & $\begin{array}{c}45.89 \mathrm{v} \\
(0.54)\end{array}$ \\
\hline 3 & $\begin{array}{l}48.79 \mathrm{~cd} \\
(0.03)\end{array}$ & $\begin{array}{l}46.64 \mathrm{x} \\
(0.01)\end{array}$ & $\begin{array}{r}102.89 \mathrm{a} \\
(1.10)\end{array}$ & $\begin{array}{l}44.71 \mathrm{vw} \\
(0.89)\end{array}$ \\
\hline 4 & $\begin{array}{c}45.77 \mathrm{~d} \\
(0.03)\end{array}$ & $\begin{array}{c}35.73 y \\
(0.01)\end{array}$ & $\begin{array}{r}102.47 \mathrm{a} \\
(1.04)\end{array}$ & $\begin{array}{l}43.12 \mathrm{w} \\
(0.61)\end{array}$ \\
\hline 5 & $\begin{array}{c}43.16 \mathrm{~d} \\
(0.03)\end{array}$ & $\begin{array}{c}27.19 \mathrm{z} \\
(0.01)\end{array}$ & $\begin{array}{r}101.86 \mathrm{a} \\
(1.33)\end{array}$ & $\begin{array}{l}41.92 w \\
(0.52)\end{array}$ \\
\hline
\end{tabular}

Means $(\mathrm{n}=5)$ in the same column followed by different letters are significantly different $(\mathrm{p} \leq 0.05)$, according to one-way ANOVA and t-test (SE shown in parentheses); a, b, c, d for B. papyrifera and u, v, w, x, y, z for M. alba.

Table 2. Effects of dehydration on leaf total, upper epidermis, palisade parenchyma, sponge parenchyma and lower epidermis thickness of Broussonetia papyrifera and Morus alba.

\begin{tabular}{|c|c|c|c|c|c|c|}
\hline $\begin{array}{l}\text { Plant } \\
\text { species }\end{array}$ & $\begin{array}{l}\text { Water loss } \\
\text { time }(\mathrm{h})\end{array}$ & Total & $\begin{array}{c}\text { Upper } \\
\text { epidermis }\end{array}$ & $\begin{array}{c}\text { Palisade } \\
\text { parenchyma }\end{array}$ & $\begin{array}{c}\text { Sponge } \\
\text { parenchyma }\end{array}$ & $\begin{array}{c}\text { Lower } \\
\text { epidermis }\end{array}$ \\
\hline & & & & $\mu \mathrm{m}$ & & 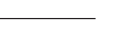 \\
\hline \multirow[t]{12}{*}{ B. papyrifera } & 0 & $72.59 \mathrm{bc}$ & $9.72 b$ & $18.26 \mathrm{~d}$ & $34.20 \mathrm{~b}$ & $10.40 \mathrm{a}$ \\
\hline & & $(1.23)$ & $(0.66)$ & $(0.45)$ & $(0.58)$ & $(0.64)$ \\
\hline & 1 & $68.49 \mathrm{c}$ & $10.57 \mathrm{ab}$ & $23.41 \mathrm{c}$ & $27.35 c$ & $7.17 \mathrm{~b}$ \\
\hline & & (1.69) & $(0.32)$ & (1.19) & $(0.51)$ & $(0.45)$ \\
\hline & 2 & $57.82 \mathrm{~d}$ & $7.09 \mathrm{c}$ & $25.60 \mathrm{c}$ & $20.19 d$ & $4.95 c$ \\
\hline & & $(2.22)$ & $(0.46)$ & $(0.72)$ & (1.53) & $(0.27)$ \\
\hline & 3 & $74.79 b$ & $10.50 \mathrm{ab}$ & $33.38 b$ & $25.40 \mathrm{c}$ & $5.51 \mathrm{c}$ \\
\hline & & $(1.55)$ & $(0.48)$ & $(0.51)$ & $(1.75)$ & $(0.45)$ \\
\hline & 4 & $97.99 \mathrm{a}$ & $10.34 \mathrm{ab}$ & $42.05 \mathrm{a}$ & $42.05 \mathrm{a}$ & $3.56 \mathrm{~d}$ \\
\hline & & $(2.82)$ & $(0.60)$ & (1.06) & $(3.25)$ & $(0.15)$ \\
\hline & 5 & $95.06 \mathrm{a}$ & $11.47 \mathrm{a}$ & $41.91 \mathrm{a}$ & $38.23 \mathrm{ab}$ & $3.45 \mathrm{~d}$ \\
\hline & & $(1.38)$ & $(0.17)$ & $(0.84)$ & $(0.71)$ & $(0.17)$ \\
\hline \multirow[t]{12}{*}{ M. alba } & 0 & $77.51 \mathrm{u}$ & $12.47 \mathrm{v}$ & $23.07 \mathrm{u}$ & $35.21 \mathrm{u}$ & $6.76 \mathrm{u}$ \\
\hline & & $(1.51)$ & $(0.34)$ & (1.12) & (1.52) & (0.59) \\
\hline & 1 & $71.60 \mathrm{v}$ & $14.60 \mathrm{u}$ & $22.12 \mathrm{u}$ & $28.30 \mathrm{v}$ & $6.58 \mathrm{u}$ \\
\hline & & (1.13) & $(1.00)$ & $(1.05)$ & $(0.46)$ & $(0.29)$ \\
\hline & 2 & $77.58 \mathrm{u}$ & $15.79 \mathrm{u}$ & $23.51 \mathrm{u}$ & $30.08 \mathrm{v}$ & $8.20 \mathrm{u}$ \\
\hline & & (1.36) & $(0.52)$ & (1.09) & (1.69) & $(0.88)$ \\
\hline & 3 & $56.05 \mathrm{w}$ & $11.77 \mathrm{v}$ & $16.82 \mathrm{v}$ & $20.13 w$ & $7.33 \mathrm{u}$ \\
\hline & & $(0.68)$ & $(0.37)$ & $(0.46)$ & $(0.36)$ & $(0.28)$ \\
\hline & 4 & $53.28 \mathrm{w}$ & $8.85 w$ & $19.38 v$ & $18.67 \mathrm{w}$ & $6.38 \mathrm{u}$ \\
\hline & & (1.80) & $(0.42)$ & $(0.77)$ & $(1.26)$ & $(0.67)$ \\
\hline & 5 & $55.83 \mathrm{w}$ & $9.65 \mathrm{w}$ & $17.83 \mathrm{v}$ & $20.92 w$ & $7.42 \mathrm{u}$ \\
\hline & & (1.19) & $(0.68)$ & $(0.51)$ & (1.70) & $(0.77)$ \\
\hline
\end{tabular}

Means $(\mathrm{n}=5)$ in the same column followed by different letters are significantly different ( $\mathrm{p} \leq 0.05)$, according to one-way ANOVA and t-test (SE shown in parentheses); a, b, c, d for B. papyrifera and u, v, w for M. alba.

between the values at 0,1 and $2 \mathrm{~h}$, and the palisade parenchyma thickness at 3,4 and $5 \mathrm{~h}$ also showed no remarkable difference. Sponge parenchyma thickness at $0 \mathrm{~h}$ was the highest. Those at 1 and $2 \mathrm{~h}$ were lower than that at $0 \mathrm{~h}$ but higher than the values at 3, 4 and $5 \mathrm{~h}$. Sponge parenchyma thickness at 3, 4 and $5 \mathrm{~h}$ showed nonsignificant difference. Lower epidermis thickness was independent on water loss moment.

The palisade-sponge ratio of $B$. papyrifera increased and reached the highest value at $3 \mathrm{~h}$ with increased water loss time, the values at 4 and $5 \mathrm{~h}$ were clearly higher than that at 0 or $1 \mathrm{~h}$ (Table 3 ). While the highest palisade-sponge ratio in $M$. alba was observed at $4 \mathrm{~h}$, and there was nonsignificant difference among the values at $0,1,2$ and $3 \mathrm{~h}$. The 
values of tightness degree of leaf tissue structure (CTR) in B. papyrifera increased with increased water loss time, and nonsignificant difference was observed between the levels ranging from 2 to $5 \mathrm{~h}$. Morus alba had the highest value of CTR at $4 \mathrm{~h}$, and there was nonsignificant difference between the values at the other moments of water loss. The values of loose degree of leaf tissue structure (SR) in B. papyrifera at 2 and $3 \mathrm{~h}$ were significantly lower than those at other levels, the SR of B. papyrifera at $0 \mathrm{~h}$ was the highest. Morus alba had the highest value of SR at $0 \mathrm{~h}$, and the values of SR at 1 , 2, 3, 4 and $5 \mathrm{~h}$ exhibited nonsignificant difference.

The highest value of leaf elastic modulus $\left(\mathrm{E}_{\mathrm{m}}\right)$ in B. papyrifera was observed at $3 \mathrm{~h}$, the values at the other moments of water loss exhibited nonsignificant difference (Figure 2). Morus alba had the lowest value of $\mathrm{E}_{\mathrm{m}}$ at $0 \mathrm{~h}$ and the highest at $4 \mathrm{~h}$. There was nonsignificant difference between the values of $\mathrm{E}_{\mathrm{m}}$ at 1,2,3 and $5 \mathrm{~h}$ in M. alba.

Table 3. Effects of dehydration on palisade-sponge ratio, tightness degree of leaf tissue structure (CTR) and loose degree of leaf tissue structure (SR) in Broussonetia papyrifera and Morus alba.

\begin{tabular}{|c|c|c|c|c|c|c|}
\hline \multirow{2}{*}{$\begin{array}{l}\text { Water loss } \\
\text { time (h) }\end{array}$} & \multicolumn{2}{|c|}{ Palisade-sponge ratio } & \multicolumn{2}{|c|}{ CTR } & \multicolumn{2}{|c|}{ SR } \\
\hline & B. papyrifera & M. alba & B. papyrifera & M. alba & B.papyrifera & M. alba \\
\hline & - & & 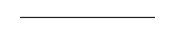 & & 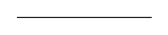 & \\
\hline 0 & $\begin{array}{c}53.41 \mathrm{e} \\
(1.16)\end{array}$ & $\begin{array}{l}66.30 \mathrm{w} \\
(5.37)\end{array}$ & $\begin{array}{c}25.20 \mathrm{c} \\
(0.82)\end{array}$ & $\begin{array}{l}29.77 \mathrm{v} \\
(1.30)\end{array}$ & $\begin{array}{c}47.14 \mathrm{a} \\
(0.66)\end{array}$ & $\begin{array}{c}45.41 \mathrm{u} \\
(1.59)\end{array}$ \\
\hline 1 & $\begin{array}{c}85.43 \mathrm{~d} \\
(3.19)\end{array}$ & $\begin{array}{l}78.35 \mathrm{vw} \\
(4.48)\end{array}$ & $\begin{array}{c}34.08 \mathrm{~b} \\
(0.91)\end{array}$ & $\begin{array}{c}30.89 \mathrm{v} \\
(1.42)\end{array}$ & $\begin{array}{c}39.96 \mathrm{~b} \\
(0.53)\end{array}$ & $\begin{array}{c}39.54 \mathrm{v} \\
(0.59)\end{array}$ \\
\hline 2 & $\begin{array}{l}129.66 \mathrm{ab} \\
(10.10)\end{array}$ & $\begin{array}{l}79.14 \mathrm{vw} \\
(5.32)\end{array}$ & $\begin{array}{c}44.39 \mathrm{a} \\
(1.11)\end{array}$ & $\begin{array}{l}30.30 \mathrm{v} \\
(1.15)\end{array}$ & $\begin{array}{l}34.76 \mathrm{c} \\
(1.69)\end{array}$ & $\begin{array}{c}38.71 \mathrm{v} \\
(1.75)\end{array}$ \\
\hline 3 & $\begin{array}{c}134.41 \mathrm{a} \\
(10.88)\end{array}$ & $\begin{array}{l}83.63 \mathrm{vw} \\
(2.65)\end{array}$ & $\begin{array}{l}44.73 \mathrm{a} \\
(1.32)\end{array}$ & $\begin{array}{c}29.99 \mathrm{v} \\
(0.59)\end{array}$ & $\begin{array}{c}33.83 \mathrm{c} \\
(1.72)\end{array}$ & $\begin{array}{c}35.92 \mathrm{v} \\
(0.52)\end{array}$ \\
\hline 4 & $\begin{array}{l}103.11 \mathrm{~cd} \\
(10.19)\end{array}$ & $\begin{array}{c}105.73 \mathrm{u} \\
(8.69)\end{array}$ & $\begin{array}{c}43.09 \mathrm{a} \\
(1.91)\end{array}$ & $\begin{array}{c}36.44 \mathrm{u} \\
(1.44)\end{array}$ & $\begin{array}{l}42.72 b \\
(2.38)\end{array}$ & $\begin{array}{c}34.96 \mathrm{v} \\
(1.49)\end{array}$ \\
\hline 5 & $\begin{array}{c}109.72 b c \\
(2.53)\end{array}$ & $\begin{array}{l}87.14 \mathrm{v} \\
(6.31)\end{array}$ & $\begin{array}{c}44.09 \mathrm{a} \\
(0.57)\end{array}$ & $\begin{array}{c}31.96 \mathrm{v} \\
(0.82)\end{array}$ & $\begin{array}{l}40.22 b \\
(0.42)\end{array}$ & $\begin{array}{c}37.34 \mathrm{v} \\
(2.41)\end{array}$ \\
\hline
\end{tabular}

Means $(\mathrm{n}=5)$ in the same column followed by different letters differ significantly at $\mathrm{p} \leq 0.05$, according to oneway ANOVA and t-test (standard errors shown in parentheses); a, b, c, d, e for B. papyrifera and $\mathrm{u}, \mathrm{v}$, w for $M$. alba.

Figure 2. Effect of dehydration on leaf elastic modulus $\left(\mathbf{E}_{\mathrm{m}}\right)$ of Broussonetia papyrifera and Morus alba.

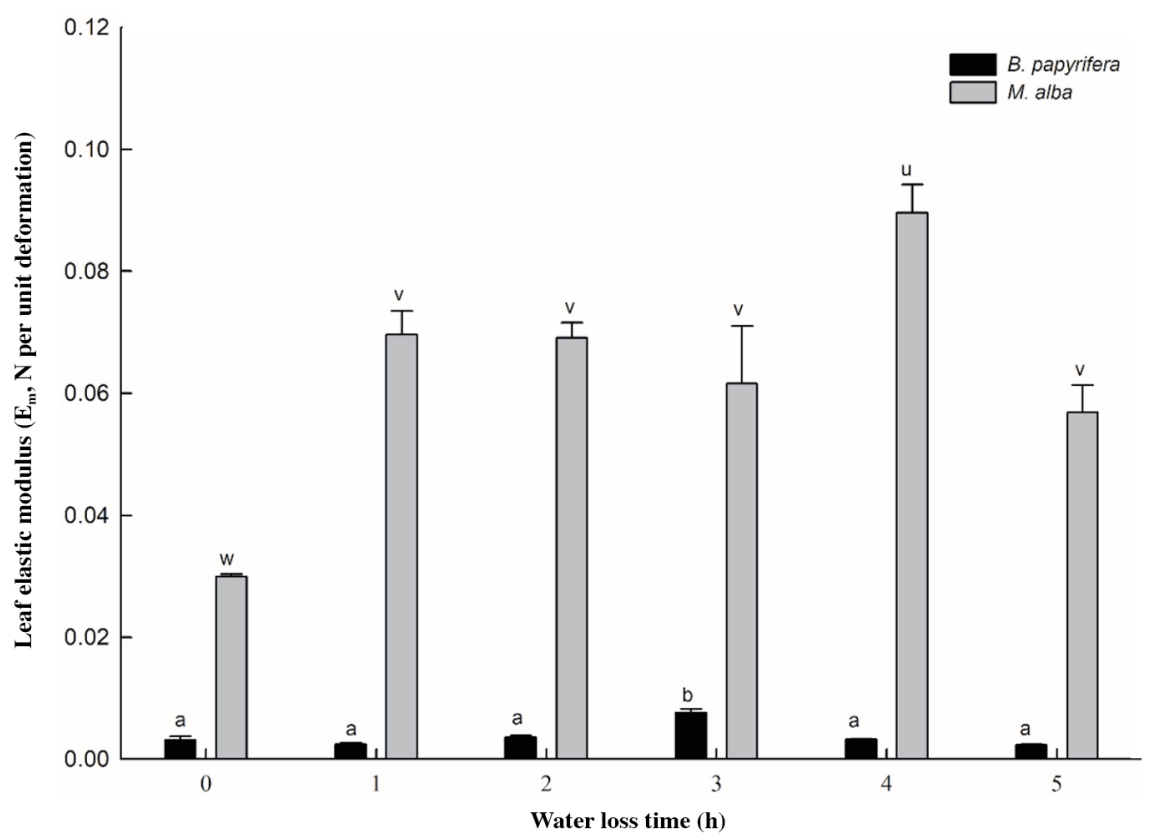

Means $\pm \operatorname{SE}(\mathrm{n}=5)$ followed by different letters in the same plant species differ significantly at $\mathrm{P} \leq 0.05$, according to one-way ANOVA and $\mathrm{t}$-test; a, b for B. papyrifera and $\mathrm{u}, \mathrm{v}, \mathrm{w}$ for M. alba. 


\section{Variation of physiological capacitance at each water loss moment}

The results of physiological capacitance (CP) variation determined by compressing the leaves with different external gripping forces are shown in Figure 3. Values of B. papyrifera and M. alba for CP displayed a positive correlation with gripping forces at each water loss moment. Broussonetia papyrifera exhibited higher $\mathrm{CP}$ values at 0 and $1 \mathrm{~h}$ under each gripping force, the values at the other water loss moments showed nonsignificant difference. Morus alba exhibited significant lower CP values at 1,2,3,4, and $5 \mathrm{~h}$ compared to that at $0 \mathrm{~h}$.

\section{Initial leaf tensity and leaf density}

The relationship between LT and gripping force $\left(\mathrm{F}_{\mathrm{g}}\right)$ displayed a good correlation and could be fitted well by the Equation 10 (Figure 3). Increase in LT was always correlated with the increase in $\mathrm{F}_{\mathrm{g}}$ at each water loss moment. The model parameters $\mathrm{y}_{0}$ and $\mathrm{k}$ were estimated using Equation 10.

The fitting equations and estimated parameter values of B. papyrifera and $M$. alba at each water loss moment are shown in Table 4. The coefficient of determination $\left(R^{2}\right)$ ranged from 0.9043 to 0.9889 . A t-test on the data showed that the differences were all significant at $\mathrm{P}<0.0001$.

The values of CP or LT were easy to be changed by the variable $\mathrm{F}_{\mathrm{g}}$, which could be avoided by determining the variation rate of the $\mathrm{LT}$ as increasing $\mathrm{F}_{\mathrm{g}}$, the coupling model between $\mathrm{F}_{\mathrm{g}}$ and $\mathrm{LT}$ was established according to the Gibbs free energy equation. Initial LT ( $\left.\mathrm{LT}_{0}\right)$ was then calculated according to Equation 11. The variations of $\mathrm{LT}_{0}$ with increased water loss time in B. papyrifera and M. alba are shown in Figure 4a. The values of $\mathrm{LT}_{0}$ in B. papyrifera at 0 and $1 \mathrm{~h}$ exhibited nonsignificant difference, the values at 2,3,4 and $5 \mathrm{~h}$ also showed nonsignificant difference, but they were significantly lower than those at 0 and $1 \mathrm{~h}$. The lowest value of $\mathrm{LT}_{0}$ in $M$. alba was observed at $2 \mathrm{~h}$, while the highest value

Figure 3. Changes of physiological capacitance with water loss time under different gripping forces $\left(F_{\mathrm{g}}\right)$ in Broussonetia papyrifera (a) and Morus alba (b). Fitting curves of the relationship between leaf tensity and gripping force at each water loss moment in B. papyrifera (c) and M. alba (d).
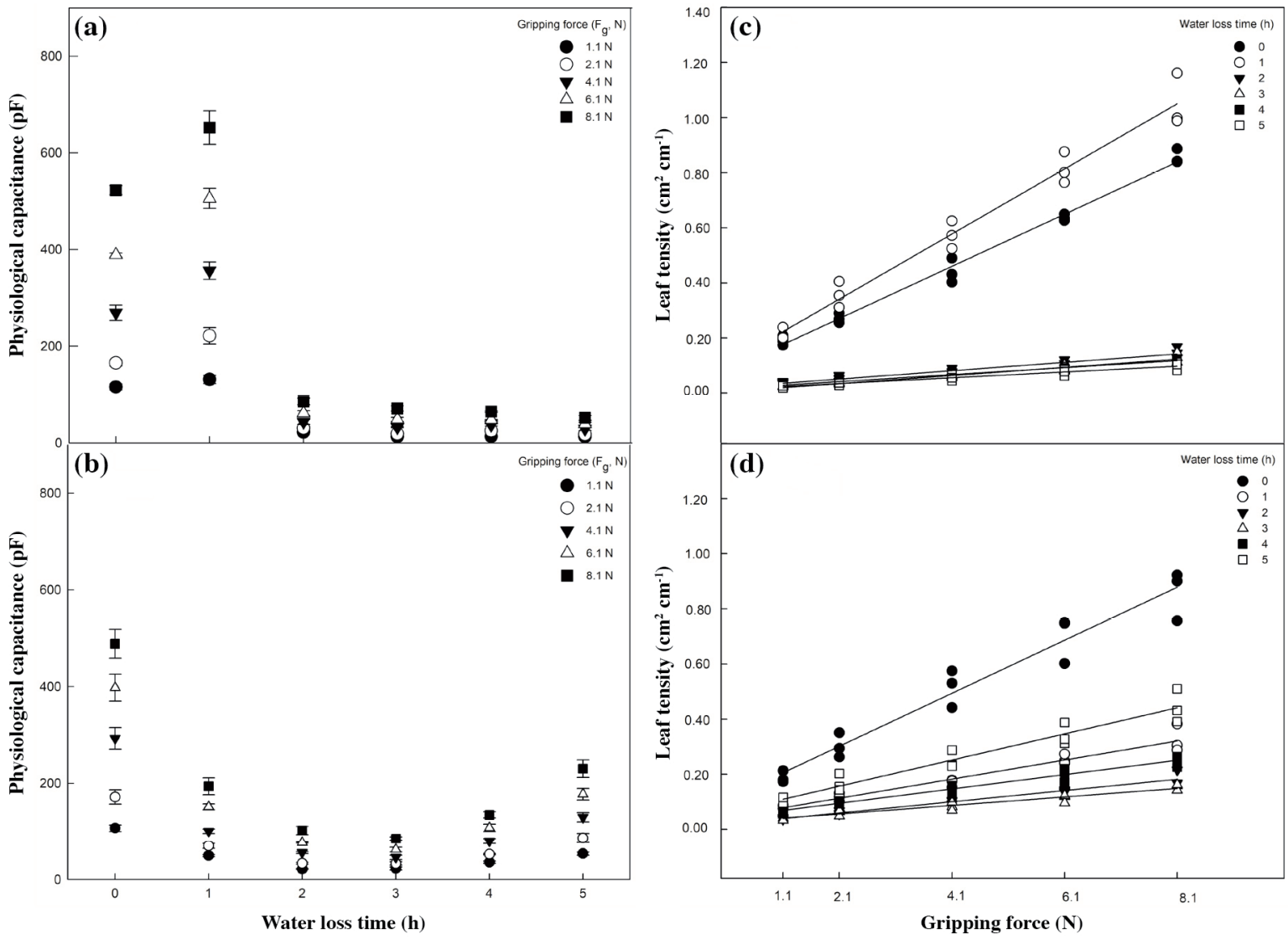
Table 4. Fitting equations of leaf tensity (LT) and gripping force $\left(\mathrm{F}_{\mathrm{g}}\right)$ at each water loss moment in Broussonetia papyrifera and Morus alba.

\begin{tabular}{lccccccc}
\hline Plant species & $\begin{array}{c}\text { Water loss } \\
\text { time }(\mathrm{h})\end{array}$ & Fitting equations & $\mathrm{n}$ & $\mathrm{R}^{2}$ & $\mathrm{y}_{0}$ & $\mathrm{k}$ & $\mathrm{P}$ \\
\hline B. papyrifera & 0 & $\mathrm{LT}=0.0716+0.0947 \mathrm{~F}_{\mathrm{g}}$ & 15 & 0.9889 & 0.0716 & 0.0947 & $<0.0001$ \\
& 1 & $\mathrm{LT}=0.0928+0.1182 \mathrm{~F}_{\mathrm{g}}$ & 15 & 0.9737 & 0.0928 & 0.1182 & $<0.0001$ \\
& 2 & $\mathrm{LT}=0.0189+0.0152 \mathrm{~F}_{\mathrm{g}}$ & 15 & 0.9075 & 0.0189 & 0.0152 & $<0.0001$ \\
& 3 & $\mathrm{LT}=0.0029+0.0148 \mathrm{~F}_{\mathrm{g}}$ & 15 & 0.9443 & 0.0029 & 0.0148 & $<0.0001$ \\
& 4 & $\mathrm{LT}=0.0148+0.0127 \mathrm{~F}_{\mathrm{g}}$ & 15 & 0.9693 & 0.0148 & 0.0127 & $<0.0001$ \\
& 5 & $\mathrm{LT}=0.0125+0.0105 \mathrm{~F}_{\mathrm{g}}$ & 15 & 0.9043 & 0.0125 & 0.0105 & $<0.0001$ \\
\hline M. alba & 0 & $\mathrm{LT}=0.0993+0.0962 \mathrm{~F}_{\mathrm{g}}$ & 15 & 0.9493 & 0.0993 & 0.0962 & $<0.0001$ \\
& 1 & $\mathrm{LT}=0.0403+0.0346 \mathrm{~F}_{\mathrm{g}}$ & 15 & 0.9410 & 0.0403 & 0.0346 & $<0.0001$ \\
& 2 & $\mathrm{LT}=0.0165+0.0204 \mathrm{~F}_{\mathrm{g}}$ & 15 & 0.9581 & 0.0165 & 0.0204 & $<0.0001$ \\
& 3 & $\mathrm{LT}=0.0234+0.0154 \mathrm{~F}_{\mathrm{g}}$ & 15 & 0.9292 & 0.0234 & 0.0154 & $<0.0001$ \\
& 4 & $\mathrm{LT}=0.0400+0.0260 \mathrm{~F}_{\mathrm{g}}$ & 15 & 0.9600 & 0.0400 & 0.0260 & $<0.0001$ \\
& 5 & $\mathrm{LT}=0.0569+0.0475 \mathrm{~F}_{\mathrm{g}}$ & 15 & 0.9354 & 0.0569 & 0.0475 & $<0.0001$ \\
\hline
\end{tabular}

$\mathrm{R}^{2}$ : Coefficient of determination; $\mathrm{y}_{0}$ and $\mathrm{k}$ : model parameters; P: significance level.

was observed at control. Lower value of $\mathrm{LT}_{0}$ was associated with longer water loss time between the levels ranging from 0 to $2 \mathrm{~h}$, while higher value of $\mathrm{LT}_{0}$ was associated with longer water loss time between the levels ranging from 3 to $5 \mathrm{~h}$. The difference of the values at 1,3,4 and $5 \mathrm{~h}$ was not remarkable.

The values of LD in B. papyrifera at $2 \mathrm{~h}$ was the highest, while those at 4 and $5 \mathrm{~h}$ were the lowest, the values at 0,1 and $3 \mathrm{~h}$ exhibited nonsignificant difference (Figure $4 \mathrm{~b}$ ). The values of LD in $M$. alba at 0,1 and $2 \mathrm{~h}$ were significantly lower than those at 3, 4 and $5 \mathrm{~h}$. The values between the levels ranging from 0 to $2 \mathrm{~h}$ exhibited nonsignificant difference, and there was also nonsignificant difference between the levels ranging from 3 to $5 \mathrm{~h}$.

\section{Maximum PSII quantum yield $\left(\mathbf{F}_{\mathrm{v}} / \mathbf{F}_{\mathrm{m}}\right)$}

The values of $\mathrm{F}_{\mathrm{v}} / \mathrm{F}_{\mathrm{m}}$ in B. papyrifera at 0 and $1 \mathrm{~h}$ were the highest, and that at $5 \mathrm{~h}$ was the lowest, while the values at 2 , 3 and $4 \mathrm{~h}$ exhibited nonsignificant difference (Figure $4 \mathrm{c}$ ). The value of $\mathrm{F}_{\mathrm{v}} / \mathrm{F}_{\mathrm{m}}$ in $M$. alba at $1 \mathrm{~h}$ showed nonsignificant difference compared to that at $0 \mathrm{~h}$. The values of $\mathrm{F}_{\mathrm{v}} / \mathrm{F}_{\mathrm{m}}$ in $M$. alba decreased significantly as increasing water loss time between the levels ranging from 1 to $5 \mathrm{~h}$.

\section{DISCUSSION}

\section{Water translocation traits in leaves of B. papyrifera}

Plants utilize various physiological and molecular strategies to cope with water deficit stress (Marín-de la Rosa et al., 2019). The present study aimed to establish a mechanism to gain insight into how plants response to dehydration. At the first hour of water loss, B. papyrifera exhibited a more significant decrease in RWC than M. alba, while its leaf internal structure responded quickly. Broussonetia papyrifera increased its palisade parenchyma thickness, palisade/sponge ratio, and CTR to maintain the leaf mechanical strength and intracellular turgor pressure. A shrinking sponge parenchyma at $1 \mathrm{~h}$ compared to that at $0 \mathrm{~h}$ reduced the transpiration and water loss to keep water balance. Compared with the control, higher CTR and lower SR at $1 \mathrm{~h}$ caused a slight increase in LD. The shrinkage of sponge parenchyma, which occupied more spaces than palisade parenchyma in leaves, offset the intracellular water loss and resulted in a slight increase in $\mathrm{LT}_{0}$. The stable cells elasticity was also conducive to the maintenance of intracellular water availability, which would sustain the stability of PSII and maintain the photosynthesis. Similar results were reported by Balsamo et al. (2015).

The further leaf water loss in B. papyrifera at $2 \mathrm{~h}$ caused a significant decrease in RWC, which remarkably reduced the leaf total thickness. However, $B$. papyrifera mitigated the water dissipation by decreasing its sponge parenchyma thickness at $2 \mathrm{~h}$ to keep the leaf water balance. As a consequence, photosynthesis might also be inhibited by the decreasing $\mathrm{CO}_{2}$ supply caused by diffusion limitations through stomata and mesophyll (Gago et al., 2020). Shrinking leaf would experience a loss of leaf internal water translocation (Scoffoni et al., 2014). A remarkable leaf longitudinal shrinkage increased the palisade/ sponge ratio and CTR, and resulted in the highest LD of B. papyrifera at $2 \mathrm{~h}$ compared to the other water loss moments. Outflow of intracellular water would moderately compensate the intercellular water loss. As a result, the leaf water status was reduced, which could also be demonstrated by the clear reduction of $\mathrm{LT}_{0}$. However, increased leaf palisade/sponge ratio and CTR of B. papyrifera enhanced the leaf water retain capacity at $2 \mathrm{~h}$, which benefited the stability of PSII. 
Figure 4. Changes of initial leaf tensity (a), leaf density (b) and maximum PSII quantum yield $\left(F_{v} / F_{m}\right)(c)$ with water loss time in Broussonetia papyrifera and Morus alba.

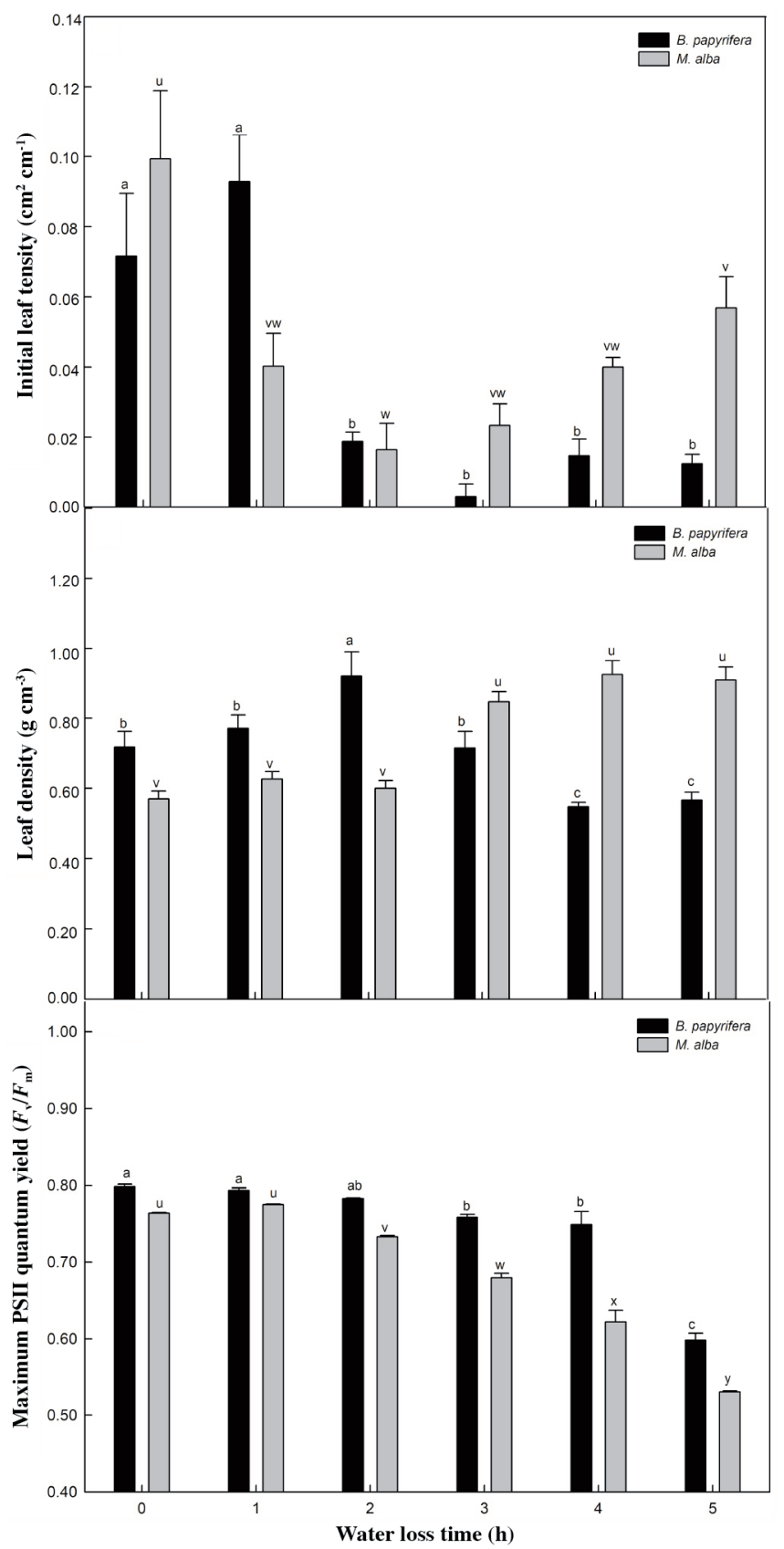

The means $\pm \operatorname{SE}(\mathrm{n}=5)$ followed by different letters in the same plant species differ significantly at $\mathrm{P} \leq 0.05$, according to one-way ANOVA and t-test; a, b, c for B. papyrifera and u, v, w, x, y for M. alba.

Leaf water dissipation in B. papyrifera was slowed down at $3 \mathrm{~h}$, which might be attributed to a further stomatal closure compared with that at $2 \mathrm{~h}$. The growth of mesophyll cells occurs mainly due to the increase in the volume of sponge parenchyma, which usually prevails over palisade parenchyma in leaves (Ennajeh et al., 2010). Although the palisade parenchyma thickness increased significantly, a decrease of mesophyll cells volume was still observed due to the decrease of sponge parenchyma thickness at $3 \mathrm{~h}$ compared with control. Water dissipation caused shrinkage in mesophyll cells at $3 \mathrm{~h}$ compared to control. However, the thickness of palisade and sponge parenchyma exhibited increases at $3 \mathrm{~h}$ compared 
to that at $2 \mathrm{~h}$, that might be attributed to the water regulation caused by enzymes, such as carbonic anhydrase (CA, EC 4.2.1.1) in cells, which catalyzed the conversion of intracellular bicarbonate into $\mathrm{H}_{2} \mathrm{O}$ and $\mathrm{CO}_{2}$ under water deficit conditions (Zhou et al., 2016). Carbonic anhydrase can be activated by the decreased intercellular $\mathrm{CO}_{2}$ concentration when the stomata were closed. This result is consistent with the results of the studies by Wu et al. (2009). Nonsignificant decrease of $\mathrm{LT}_{0}$ was observed at $3 \mathrm{~h}$ compared to that at $2 \mathrm{~h}$, which also indicated that the leaf water status was not reduced. Greater increase in leaf total thickness rather than the volumes of palisade and sponge parenchyma increased the leaf intercellular airspaces (Scoffoni et al., 2014), and reduced the LD at $3 \mathrm{~h}$ compared to that at $2 \mathrm{~h}$. Due to the cell wall hardening and increased palisade/sponge ratio, the highest value of $\mathrm{E}_{\mathrm{m}}$ in B. papyrifera was observed at $3 \mathrm{~h}$. And a stable $\mathrm{CTR}$ at $3 \mathrm{~h}$ helped to keep the intercellular water mobility. The decrease of $\mathrm{E}_{\mathrm{m}}$ in B. papyrifera at 4 and $5 \mathrm{~h}$ compared to that at $3 \mathrm{~h}$ was caused by the reduction in palisade/sponge ratio. Although the mesophyll cells and leaf total thickness increased, the LD was still reduced by a higher SR at 4 and $5 \mathrm{~h}$ compared to that at $3 \mathrm{~h}$, no severe leaf water dissipation was observed at 4 and $5 \mathrm{~h}$. However, a severe damage of dehydration stress on PSII of B. papyrifera was observed at $5 \mathrm{~h}$.

\section{Water translocation traits in leaves of $M$. alba}

The spongy parenchyma contributes to the improvement of gas exchange, while its shrinkage is not conducive to the gas exchange, and therefore the transpiration (Vitalevna et al., 2019). The decline of leaf total thickness in M. alba was mainly caused by the shrinkage of sponge parenchyma at the first hour of water loss, which limited the transpiration and might simultaneously inhibit the photosynthesis. Prevention of leaf water dissipation and the shrinkage of mesophyll cells kept the intracellular water balance at $1 \mathrm{~h}$. Because of the increased upper epidermis thickness and palisade/sponge ratio, leaf mechanical strength was enhanced, which caused an increase in $\mathrm{E}_{\mathrm{m}}$ compared with control $(0 \mathrm{~h})$. Compared to B. papyrifera, M. alba exhibited a slighter decrease in RWC and a higher ability to maintain the normal physiological and biochemical processes at $1 \mathrm{~h}$. And the simultaneous slight shrinkage of leaf and mesophyll cells caused by water loss maintained the CTR and LD. Although the leaf water status was reduced, the water loss at $1 \mathrm{~h}$ exhibited nonsignificant damage on the PSII of M. alba.

The leaf internal structure and mesophyll cells volume of $M . a l b a$ at $2 \mathrm{~h}$ did not exhibit significant difference compared with $1 \mathrm{~h}$. Therefore, M. alba maintained stable values of $\mathrm{E}_{\mathrm{m}}$ and LD at $2 \mathrm{~h}$. The relationship between leaf structure and mechanical properties has also been reported by Liu et al. (2018). However, the slight decrease of leaf water status at $2 \mathrm{~h}$ compared with $1 \mathrm{~h}$ caused a significant reduction in $\mathrm{F}_{\mathrm{v}} / \mathrm{F}_{\mathrm{m}}$. As water loss increased, the RWC, mesophyll cells volume and leaf total thickness of $M$. alba at $3 \mathrm{~h}$ reduced by $20.50 \%, 31.05 \%$ and $27.75 \%$ of that at $2 \mathrm{~h}$, respectively. The shrinkage of mesophyll cells decreased the volume but offset the intracellular water loss, and the outflow of the intracellular water caused by cells shrinkage mitigated the shrinking of leaves. Greater decrease in mesophyll cells volume rather than intracellular water content, together with the simultaneous remarkable leaf shrinkage, increased the LD of M. alba at 3 $\mathrm{h}$. A stable CTR and palisade/sponge ratio kept the leaf mechanical strength and cells elasticity at $3 \mathrm{~h}$ compared with $2 \mathrm{~h}$. The decreased intracellular water mobility caused a significant damage on PSII of M. alba.

No further variation of leaf thickness, mesophyll cell volume and LD were observed between the levels ranging from 3 to $5 \mathrm{~h}$ due to the over desiccation. The $3 \mathrm{~h}$ might be a threshold for $M$. alba to resistant to dehydration. The highest value of $\mathrm{E}_{\mathrm{m}}$ was observed at $4 \mathrm{~h}$, which was attributed to the highest palisade/sponge ratio and CTR, that enhanced the leaf mechanical strength. However, this would not benefit the leaf intracellular water availability, the PSII of M. alba was damaged and the values of $\mathrm{F}_{\mathrm{v}} / \mathrm{F}_{\mathrm{m}}$ decreased significantly.

\section{Differential response traits between the two Moraceae plant species}

Under dehydration stress, B. papyrifera and M. alba responded differently in terms of leaf structure and intracellular water status. As water loss time increased, the intracellular water availability of $M$. alba was limited earlier than that of B. papyrifera. Broussonetia papyrifera adapted to dehydration stress by shrinking its mesophyll cells to offset the intracellular water loss, or triggering water regulation mechanism caused by enzymes, such as $\mathrm{CA}$, which catalyzed the conversion of intracellular bicarbonate into $\mathrm{H}_{2} \mathrm{O}$ and $\mathrm{CO}_{2}$ under water deficit conditions (Figure 5). However, M. alba maintained the intracellular water availability just by changing the leaf internal structure (Figure 5). Similar results were reported by Ding et al. (2020). The offset effects for intracellular water loss by shrinking mesophyll cells differed between B. papyrifera and M. alba, because the elastic-plastic behavior of their leaves and cells were different. 
Figure 5. Variation of cell volume and intracellular water loss under dehydration stress.

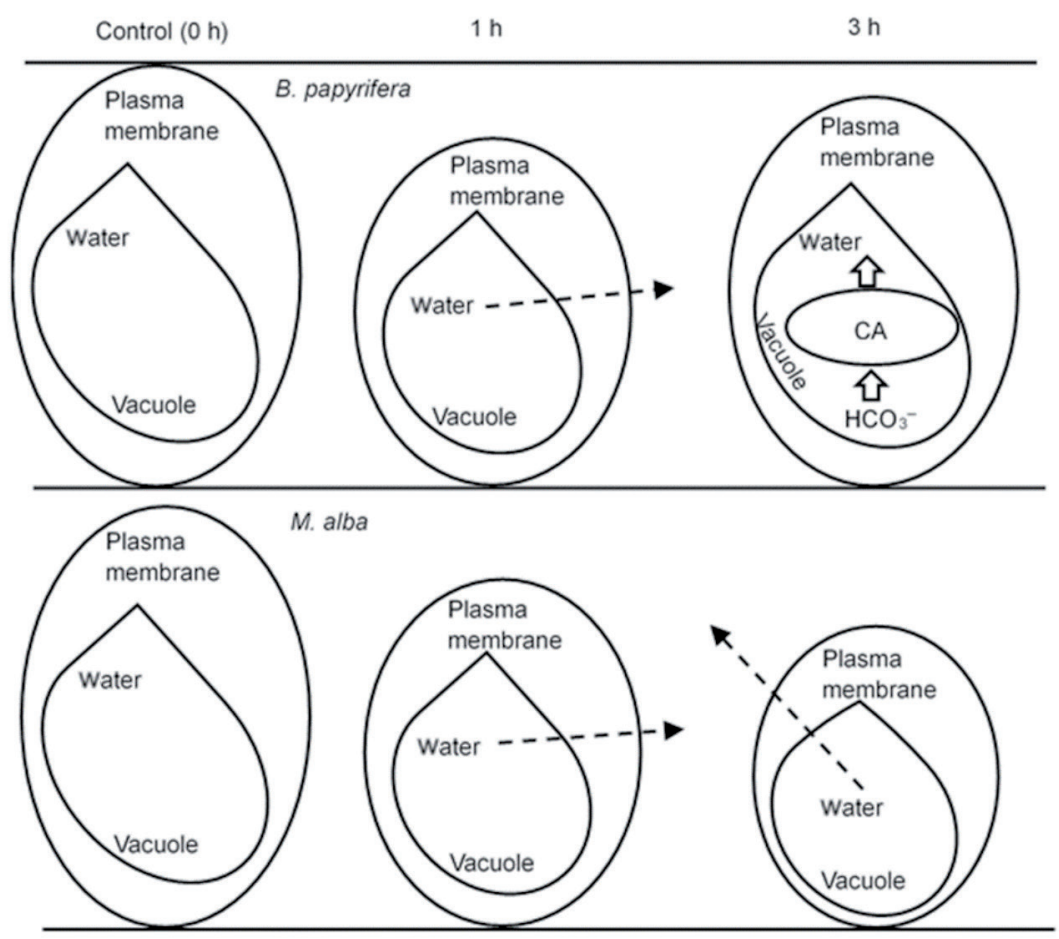

Note: Shrinkage of mesophyll cells offset the intracellular water loss at $1 \mathrm{~h}$, the stable cells elasticity also helped keep the intracellular water availability of Broussonetia papyrifera. The water regulation caused by enzymes, such as carbonic anhydrase (CA), might change the water status of $B$. papyrifera at $3 \mathrm{~h}$. Consequently, the mesophyll cells volume of $B$. papyrifera increased at $3 \mathrm{~h}$ compared to that at 1 or $2 \mathrm{~h}$, and the intracellular water availability was maintained. While Morus alba continued to shrink its mesophyll cells, but the cells kept a stable cells elasticity at $3 \mathrm{~h}$ compared with $2 \mathrm{~h}$. The decreased cells volume offset the intracellular water loss at $3 \mathrm{~h}$, and the outflow of the intracellular water caused by cells shrinkage happened simultaneously. As a result, the intracellular water availability was maintained, which could be represented by the unchanged initial leaf tensity $\left(\mathrm{LT}_{0}\right)$.

\section{CONCLUSIONS}

To maintain leaf intracellular water availability during dehydration, different species of plants respond differently by changing leaf internal structure and intracellular water status. In this research, Broussonetia papyrifera quickly changed the leaf internal structure to adapt to dehydration stress. The intracellular water availability of Morus alba was more sensitive than B. papyrifera. Broussonetia papyrifera adapted to dehydration stress by shrinking its mesophyll cells to offset the water loss, or triggering water regulation mechanism. Morus alba maintained intracellular water availability just by changing the leaf structure. The offset effects through shrinking cells differed between B.papyrifera and M. alba, because the elastic-plastic behavior of their leaves and cells were different. The $3 \mathrm{~h}$ might be a dehydration tolerance threshold for M. alba. Similarly, leaf mild wilting under water deficit conditions is also a kind of mechanism for natural grown plants to regulate the intracellular water availability. We have found that monitoring of plant water status would be more accurate in terms of mechanical strength and electrophysiology instead of water content measurements. The mechanical strength and electrophysiological indexes would promote the screening speed of drought-tolerant species, and improve the water use efficiency in the arid areas. 


\section{ACKNOWLEDGEMENTS}

We thank Janusz J. Zwiazek for his constructive comments on the manuscript. This work was supported by the project of the National Natural Science Foundation of China (U1612441); the National Key Research and Development Program of China (2016YFC0502602); the fund of the "Outstanding Young and Middle-Aged University Teachers and Presidents Training Abroad Project" of Jiangsu Province; and the Priority Academic Program Development (PAPD) of Jiangsu Higher Education Institutions.

\section{REFERENCES}

Afzal, A., Duiker, S.W., and Watson, J.E. 2017. Leaf thickness to predict plant water status. Biosystems Engineering 156:148-156.

Balsamo, R., Boak, M., Nagle, K., Peethambaran, B., and Layton, B. 2015. Leaf biomechanical properties in Arabidopsis thaliana polysaccharide mutants affect drought survival. Journal of Biomechanics 48:4124-4129.

Bochicchio, A., Vazzana, C., Puliga, S., Alberti, A., Cinganelli, S., and Vernieri, P. 1998. Moisture content of the dried leaf is critical to desiccation tolerance in detached leaves of the resurrection plant Boea hygroscopica. Plant Growth Regulation 24:163-170.

Boyer, J.S. 2015. Turgor and the transport of $\mathrm{CO}_{2}$ and water across the cuticle (epidermis) of leaves. Journal of Experimental Botany 66:2625-2633.

Ding, J., Johnson, E.A., and Martin, Y.E. 2020. Optimization of leaf morphology in relation to leaf water status: A theory. Ecology and Evolution 10:1501-1525.

El-Sayed, I.M., Shaaban, S.A., Taha, L.S., and Mahgoub, M.H. 2019. Anatomical structure and micropropagation ability of Populus alba L. under effect of drought stress. Plant Archives 19:2655-2663.

Ennajeh, M., Vadel, A.M., Cochard, H., and Khemira, H. 2010. Comparative impacts of water stress on the leaf anatomy of a drought-resistant and a drought-sensitive olive cultivar. Journal of Horticultural Science \& Biotechnology 85:289-294.

Gago, J., Daloso, D.M., Carriquí, M., Nadal, M., Morales, M., Araújo, W.L., et al. 2020. The photosynthesis game is in the "inter-play": Mechanisms underlying $\mathrm{CO}_{2}$ diffusion in leaves. Environmental and Experimental Botany 178:104174.

García-Orellana, Y., Ortuño, M.F., Conejero, W., and Ruiz-Sánchez, M.C. 2013. Diurnal variations in water relations of deficit irrigated lemon trees during fruit growth period. Spanish Journal of Agricultural Research 11:137-145.

Huang, H.M., Zhao, Y.L., Xu, Z.G., Zhang, W., and Jiang, K.K. 2019. Physiological responses of Broussonetia papyrifera to manganese stress, a candidate plant for phytoremediation. Ecotoxicology and Environmental Safety 181:18-25.

Li, Z.L. 1978. Plant section technique. Science Press, Beijing, China.

Li, X., He, X., Smith, R., Choat, B., and Tissue, D. 2020. Temperature alters the response of hydraulic architecture to $\mathrm{CO}_{2}$ in cotton plants (Gossypium hirsutum). Environmental and Experimental Botany 172:104004.

Liu, J., Zhang, Z., Yu, Z., Liang, Y., Li, X., and Ren, L. 2018. Experimental study and numerical simulation on the structural and mechanical properties of Typha leaves through multimodal microscopy approaches. Micron 104:37-44.

Mahmoodi-Sourestani, M. 2013. Diurnal variations of gas exchange characteristics in leaves of anise hyssop (Agastache foeniculum) under normal, drought stress and recovery conditions. Journal of Medicinal Plants and By-products 1:91-101.

Malgat, R., Faure, F., and Boudaoud, A. 2016. A mechanical model to interpret cell-scale indentation experiments on plant tissues in terms of cell wall elasticity and turgor pressure. Frontiers in Plant Science 7:1351.

Marín-de la Rosa, N., Lin, C.W., Kang, Y.J., Dhondt, S., Gonzalez, N., Inzé, D., et al. 2019. Drought resistance is mediated by divergent strategies in closely related Brassicaceae. New Phytologist 223:783-797.

Méndez-Alonzo, R., Ewers, F.W., Jacobsen, A.L., Pratt, R.B., Scoffoni, C., Bartlett, M.K., et al. 2019. Covariation between leaf hydraulics and biomechanics is driven by leaf density in Mediterranean shrubs. Trees 33:507-519.

Pirzad, A., Shakiba, M.R., Zehtab-Salmasi, S., Mohammadi, S.A., Darvishzadeh, R., and Samadi, A. 2011. Effect of water stress on leaf relative water content, chlorophyll, proline and soluble carbohydrates in Matricaria chamomilla L. Journal of Medicinal Plants Research 5:2483-2488.

Poorter, H., Niinemets, Ü., Poorter, L., Wright, I.J., and Villar, R. 2009. Causes and consequences of variation in leaf mass per area (LMA): a meta-analysis. New Phytologist 182:565-588.

Salgado-Aguilar, M., Molnar, T., Pons-Hernández, J.L., Covarrubias-Prieto, J., Ramírez-Pimentel, J.G., Raya-Pérez, J.C., et al. 2020. Physiological and biochemical analyses of novel drought-tolerant maize lines reveal osmoprotectant accumulation at silking stage. Chilean Journal of Agricultural Research 80:241-252.

Scoffoni, C., Vuong, C., Diep, S., Cochard, H., and Sack, L. 2014. Leaf shrinkage with dehydration: Coordination with hydraulic vulnerability and drought tolerance. Plant Physiology 164:1772-1788.

Sun, M., Yang, S.J., Zhang, J.L., Bartlett, M., and Zhang, S.B. 2014. Correlated evolution in traits influencing leaf water balance in Dendrobium (Orchidaceae). Plant Ecology 215:1255-1267. 
Vastag, E., Cocozza, C., Orlović, S., Kesić, L., Kresoja, M., and Stojnić, S. 2020. Half-sib lines of pedunculate oak (Quercus robur L.) respond differently to drought through biometrical, anatomical and physiological traits. Forests 11:1-21.

Vitalevna, P.O., Dmitrievna, G.O., Dmitrievich, K.S., and Vitalevna, K.O. 2019. Physiological features of red currant adaptation to drought and high air temperatures. p. 1-13. In Ondrasek, G. (ed.) Drought-detection and solutions. IntechOpen, London, UK.

Wu, Y.Y., Liu, C.Q., Li, P.P., Wang, J.Z., Xing, D., and Wang, B.L. 2009. Photosynthetic characteristics involved in adaptability to Karst soil and alien invasion of paper mulberry (Broussonetia papyrifera (L.) Vent.) in comparison with mulberry (Morus alba L.) Photosynthetica 47:155-160.

Wu, Y.Y., and Xing, D.K. 2012. Effect of bicarbonate treatment on photosynthetic assimilation of inorganic carbon in two plant species of Moraceae. Photosynthetica 50:587-594.

Wyka, T.P., Bagniewska-Zadworna, A., Kuczynska, A., Mikolajczak, K., Ogrodowicz, P., Zytkowiak, M., et al. 2019. Droughtinduced anatomical modifications of barley (Hordeum vulgare L.) leaves: An allometric perspective. Environmental and Experimental Botany 166:103798.

Xing, D.K., Chen, X.L., Wu, Y.Y., Chen, Q., Li, L., Fu, W.G., et al. 2019. Leaf stiffness of two Moraceae species based on leaf tensity determined by compressing different external gripping forces under dehydration stress. Journal of Plant Interactions 14:610-616

Xiong, D.L., Wang, D., Liu, X., Peng, S.B., Huang, J.L., and Li, Y. 2016. Leaf density explains variation in leaf mass per area in rice between cultivars and nitrogen treatments. Annals of Botany 117:963-971.

Zhang, Z., Huang, M., Zhao, X., and Wu, L. 2019. Adjustments of leaf traits and whole plant leaf area for balancing water supply and demand in Robinia pseudoacacia under different precipitation conditions on the Loess Plateau. Agricultural and Forest Meteorology 279:107733.

Zhang, P.P., Mu, F., Song, H., Qu, Y., Wang, P.K., and Feng, B.L. 2013. Anatomical structure and drought resistance in broomcorn millet leaf. Transactions of the Chinese Society for Agricultural Machinery 44:119-126. (in Chinese).

Zhang, M., Wu, Y., Xing, D., Zhao, K., and Yu, R. 2015. Rapid measurement of drought resistance in plants based on electrophysiological properties. Transactions of the ASABE 58:1441-1446.

Zhou, W., Sui, Z., Wang, J., Hu, Y., Kang, K.H., Hong, H.R., et al. 2016. Effects of sodium bicarbonate concentration on growth, photosynthesis, and carbonic anhydrase activity of macroalgae Gracilariopsis lemaneiformis, Gracilaria vermiculophylla, and Gracilaria chouae (Gracilariales, Rhodophyta). Photosynthesis Research 128:259-270. 